\title{
WYMYWANIE WYBRANYCH METALI CIĘŻKICH Z BETONÓW ZAWIERAJĄCYCH POPIÓŁ Z TERMICZNEGO PRZEKSZTAŁCANIA OSADÓW ŚCIEKOWYCH
}

\author{
Piotr Wichowski ${ }^{\bowtie}$, Gabriela Rutkowska, Piotr Nowak \\ Wydział Budownictwa i Inżynierii Środowiska, Szkoła Główna Gospodarstwa Wiejskiego w Warszawie, Warszawa
}

\begin{abstract}
STRESZCZENIE
Celem pracy było określenie wartości wymywania wybranych metali ciężkich z betonów zwykłych klasy C16/20, zawierających $15 \%$ popiołów lotnych pochodzących z termicznego przekształcania osadów ściekowych w stosunku do obliczonej ilości cementu. Próbki betonów rozdrobniono na frakcje poniżej 4 oraz poniżej $1 \mathrm{~mm}$, które następnie poddano wymywaniu, a w powstałym eluacie oznaczono zawartość $\mathrm{Cd}, \mathrm{Cr}, \mathrm{Cu}$, $\mathrm{Ni}, \mathrm{Pb}, \mathrm{Zn}, \mathrm{As}, \mathrm{Sb}$ oraz Se. Stwierdzone stężenia metali są znacznie poniżej wartości maksymalnych, określonych w wymogach, jakie należy spełnić przy wprowadzaniu ścieków do wód lub do ziemi oraz w sprawie substancji szczególnie szkodliwych dla środowiska wodnego, a także granicznych wartości wymywania wymaganych przy dopuszczaniu odpadów obojętnych do składowania. Na tej podstawie stwierdzono, że migracja metali ciężkich z betonów z dodatkiem popiołów do środowiska wodnego jest nieznaczna i nie powinna stanowić istotnego problemu. Badania wymagają jednak kontynuacji dla różnych klas i rodzajów betonu oraz zróżnicowanych warunków wymywania.
\end{abstract}

Słowa kluczowe: popiół uzyskany z termicznego przekształcania osadów ściekowych, metale ciężkie, wymywanie

\section{WSTĘP}

Należy dążyć do ograniczenia ilości odpadów, które nie mogą być wykorzystane i w związku z tym muszą być deponowane na składowiskach. Według danych statystycznych Głównego Urzędu Statystycznego (GUS, 2017) w 2014 roku w krajowych oczyszczalniach ścieków komunalnych i przemysłowych łącznie wytworzono 967,4 tys. ton suchej masy osadów ściekowych. Racjonalna gospodarka osadami ściekowymi, zwłaszcza na terenach zurbanizowanych, powinna prowadzić do wykorzystania termicznych metod ich przekształcania. W 2008 roku termicznie przekształcano niewiele ponad 1\% wytworzonych osadów, a w 2014 roku - już blisko 15,1\%, tendencja ta jest cały czas rosnąca (Uchwała nr 88 Rady Ministrów w sprawie Krajowego planu gospodarki odpadami 2022, 2016). W efekcie powstaje znacząca ilość odpadów z termicznego przekształcania osadów ściekowych. Odpady te mogą stać się produktem wykorzystywanym jako dodatek lub częściowo zamiennik cementu do produkcji betonów (Pietrzak, 2014). Przeprowadzone badania wskazują na możliwość uzyskania podobnych parametrów wytrzymałościowych dla betonów popiołowych zawierających do $10 \%$ popiołów lotnych jako zamiennik lub dodatek do cementu i betonów bez dodatku popiołu (Kosior-Kazberuk, 2011; Rutkowska i Iwaszko,

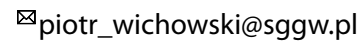


Wichowski, P., Rutkowska, G. i Nowak, P. (2017). Wymywanie wybranych metali ciężkich z betonów zawierających popiół z termicznego przekształcania osadów ściekowych. Acta Sci. Pol. Architectura, 16 (1), 43-51. doi: 10.22630/ASPA.2017.16.1.05.

2015; Rutkowska, Wichowski i Mroczkowska, 2016; Rutkowska, Wiśniewski, Chalecki, Górecka i Miłosek, 2016). Przy porównywalnej wytrzymałości betony popiołowe mogą być konkurencyjne cenowo w stosunku do betonów bez dodatku popiołu. Obecnie dość szeroko do produkcji betonu wykorzystywane są popioły lotne powstające ze spalania konwencjonalnych paliw w elektrociepłowniach, a brakuje wdrożeń wykorzystujących popioły lotne z termicznego przekształcania osadów ściekowych. Wysuszone osady ściekowe wykorzystuje się jako niekonwencjonalne paliwo i współspala z pyłem węglowym w piecach cementowych (Bień, 2012).

Istotnym zagadnieniem jest oddziaływanie obiektów inżynierskich (w tym materiałów, z jakich zostały wykonane) na środowisko naturalne. Osady ściekowe i popioły lotne uzyskane $\mathrm{z}$ ich termicznego przekształcania zawierają metale ciężkie o różnym stopniu mobilności (Wang, Hu, Chen i Wu, 2005; Wilk i Gworek, 2009; Gawdzik i Latosińska, 2014). Należy określić zatem potencjalne zagrożenia związane z oddziaływaniem materiału, z jakiego została wykonana konstrukcja betonowa, na lokalne ekosystemy.

Celem przeprowadzonych badań było określenie wartości wymywania wybranych metali ciężkich z betonów zwykłych zawierających popioły lotne z termicznego przekształcania osadów ściekowych. Jest to istotne zarówno na etapie eksploatacji obiektu budowlanego, jak i w okresie poeksploatacyjnym, kiedy materiały z rozebranego obiektu budowlanego przewidziane są do składowania lub ponownego wykorzystania.

\section{MATERIAt I METODY}

Popiół lotny jest to drobno uziarniony pył, składający się głównie z kulistych, zeszkliwionych ziaren, otrzymywanych przy spalaniu pyłu węglowego, z udziałem lub bez udziału materiałów współspalanych, wykazujący właściwości pucolanowe i zawierający przede wszystkim $\mathrm{SiO}_{2} \mathrm{i} \mathrm{Al}_{2} \mathrm{O}_{3}$, przy czym zawartość reaktywnego $\mathrm{SiO}_{2}$ wynosi co najmniej 25\% masy (PN-EN 450-1: 2009. Popiół lotny do betonu. Część 1: Definicje, specyfikacje i kryteria zgodności). Do badań wykorzystano popioły lotne (rys. 1b) uzyskane ze spalania wysuszonych osadów ściekowych (rys. 1a) pochodzących z Oczyszczalni Ścieków „Czajka” w Warszawie. Do ich termicznego przekształcenia doszło w Stacji Termicznej Utylizacji Osadów Ściekowych położonej na terenie oczyszczalni, wykorzystującej technologię spalania w złożu fluidalnym.

Zawartość metali ciężkich w popiołach lotnych wykorzystanych do badań przedstawiono w tabeli 1. Dodatkowo wybrane parametry popiołów lotnych wykorzystanych do badań przedstawiono w tabeli 2. Reagenty te w sprzyjających warunkach mogą powodować korozję chemiczną betonu, prowadząc do jego spękania i w efekcie odsłonięcia zbrojenia.

Przy projektowaniu betonów należy zadecydować, czy wykonywanie betonu będzie odbywać się w warunkach przemysłowych, przeciętnych czy prymitywnych. W przeprowadzonych badaniach założono wykonanie betonu w warunkach przeciętnych. W tych warunkach projektuje się klasę betonu do C20/25 (Jamroży, 2009). Na potrzeby eksperymentu wykonano mieszanki betonowe (beton) klasy C16/20 o konsystencji gęstoplastycznej. Mieszanki betonowe przygotowano w laboratorium budowlanym Wydziału Budownictwa i Inżynierii Środowiska SGGW w Warszawie. Ilość składników mieszanki betonowej obliczono metodą trzech równań według Bukowskiego (Jamroży, 2009). Próbki betonu do badań zaprojektowano jako beton zwykły zgodnie z normą PN-EN 206:2014-04. Beton. Wymagania, właściwości, produkcja i zgodność. Do przygotowania próbek betonu wykorzystano cement portlandzki CEM I 32,5R, kruszywo naturalne o średnicy maksymalnej $16 \mathrm{~mm}$, popiół lotny pochodzący z oczyszczalni ścieków „Czajka” w Warszawie oraz wodę. Badania wybranych parametrów wytrzymałościowych przeprowadzono dla pięciu serii próbek betonowych:

1) bez popiołu lotnego - seria kontrolna,

2) z dodatkiem $10 \%$ popiołu do zakładanej ilości cementu,

3) z zamianą $10 \%$ cementu na popiół,

4) $\mathrm{z}$ dodatkiem $15 \%$ popiołu do zakładanej ilości cementu,

5) z zamianą $15 \%$ cementu na popiół. 
Wichowski, P., Rutkowska, G. i Nowak, P. (2017). Wymywanie wybranych metali ciężkich z betonów zawierających popiół z termicznego przekształcania osadów ściekowych. Acta Sci. Pol. Architectura, 16 (1), 43-51. doi: 10.22630/ASPA.2017.16.1.05.

Tabela 1. Zawartość metali ciężkich w popiołach lotnych wykorzystanych do badań $\left(\mathrm{w} \mathrm{mg} \cdot \mathrm{kg} \mathrm{s.m.} .^{-1}\right)$ - opr. autora na podstawie materiałów uzyskanych z oczyszczalni „Czajka”

Table 1. Content of heavy metals in fly ashes used in the tests (in $\mathrm{mg} \cdot \mathrm{kg} \mathrm{d} . \mathrm{m} \cdot{ }^{-1}$ ) - worked out by the author basing on the materials obtained in the "Czajka" sewage treatment plant

\begin{tabular}{lcc}
\hline \multirow{2}{*}{$\begin{array}{l}\text { Oznaczany parametr } \\
\text { Tested parameter }\end{array}$} & \multicolumn{2}{c}{ Wyniki badań - Results } \\
\cline { 2 - 3 } Sucha masa - Solid (\%) & Zakres zmienności - Variability range & Średnia - Average \\
Arsen - Arsenic (As) & $<1,0$ & 99,5 \\
Bar - Bar (Ba) & $<1,0$ & - \\
Kadm - Cadmium (Cd) & $<0,13$ & - \\
Chrom - Chromium (Cr) & $0,1-0,14$ & 0,11 \\
Miedź - Copper (Cu) & $<0,25$ & - \\
Rtęć - Mercury (Hg) & $<0,005$ & - \\
Nikiel - Nickel (Ni) & $<0,25$ & $<0,25$ \\
Ołów - Lead (Pb) & $<0,25$ & $<0,25$ \\
Antymon - Antimony (Sb) & $<0,02 \div 0,28$ & $<0,02$ \\
Selen - Selene (Se) & $0,13-1,44$ & 0,52 \\
Cynk - Zinc (Zn) & $<1,0$ & - \\
\hline
\end{tabular}

Tabela 2. Wybrane właściwości chemiczne popiołów lotnych (w $\left.\mathrm{mg} \cdot \mathrm{kg} \mathrm{s} . \mathrm{m}^{-1}{ }^{-1}\right)$ opr. autora na podstawie materiałów uzyskanych z oczyszczalni „Czajka”

Table 2. Selected chemical properties of fly ashes (in $\mathrm{mg} \cdot \mathrm{kg} \mathrm{d} \cdot \mathrm{m}^{-1}{ }^{-1}$ - worked out by the author basing on the materials obtained in the "Czajka" sewage treatment plant

\begin{tabular}{lcc}
\hline \multirow{2}{*}{$\begin{array}{l}\text { Oznaczany parametr } \\
\text { Tested parameter }\end{array}$} & \multicolumn{2}{c}{ Wyniki badań - Results } \\
\cline { 2 - 3 } & Zakres zmienności - Variability range & Średnia - Average \\
\hline Chlorki - Chlorides $\left(\mathrm{Cl}^{-}\right)$ & $67,5-123$ & 94,8 \\
Fluorki - Fluorides $\left(\mathrm{F}^{-}\right)$ & $5-40$ & 8504 \\
Siarczany - Sulphates $\left(\mathrm{SO}_{4}^{2-}\right)$ & $7900-9290$ & 21,3 \\
Rozpuszczony węgiel organiczny & $10-47,1$ & 15430 \\
Dissolved organic carbon & & \\
Stałe związki rozpuszczone & $14000-16650$ & \\
Total dissolved compounds & &
\end{tabular}

Receptury mieszanki betonowej na jeden zarób dla badanych serii próbek w ilości $77 \mathrm{dm}^{3}$, ustalone metodą trzech równań, podano w tabeli 3.

Badania wytrzymałościowe wykazały porównywalne parametry mechaniczne analizowanych próbek z wyjątkiem próbek z zamianą 15\% cementu na popiół lotny. Przykładowo po 90 dniach dojrzewania średnia wytrzymałość na ściskanie próbek bez dodatku popiołu wynosiła 46,4 MPa przy zakresie zmienności 46,3-46,6 MPa, serii z dodatkiem 10\% popiołu - 48,5 MPa (47,8-49,2), z zamianą 10\% cementu na popiół 
Wichowski, P., Rutkowska, G. i Nowak, P. (2017). Wymywanie wybranych metali ciężkich z betonów zawierających popiół z termicznego przekształcania osadów ściekowych. Acta Sci. Pol. Architectura, 16 (1), 43-51. doi: 10.22630/ASPA.2017.16.1.05.

Tabela 3. Receptura mieszanki betonowej na jeden zarób

Table 3. Recipe of the concrete mix for one portion

\begin{tabular}{|c|c|c|c|c|c|}
\hline \multirow[b]{2}{*}{$\begin{array}{l}\text { Składniki mieszanki } \\
\text { Components } \\
\text { of the mixture }\end{array}$} & \multicolumn{5}{|c|}{$\begin{array}{l}\text { Masa poszczególnych składników w badanych seriach próbek }[\mathrm{kg}] \\
\text { The mass of the individual components in investigated concrete samples }[\mathrm{kg}]\end{array}$} \\
\hline & $\begin{array}{c}\text { Bez dodatku } \\
\text { popiołu } \\
\text { Without } \\
\text { fly ash }\end{array}$ & $\begin{array}{c}\text { Dodatek } 10 \% \\
\text { popiołu lotnego } \\
\text { do określonej } \\
\text { ilości cementu } \\
\text { Addition of } 10 \% \text { fly } \\
\text { ash to a specified } \\
\text { quantity of cement }\end{array}$ & $\begin{array}{c}\text { Zamiana } 10 \% \\
\text { cementu } \\
\text { na popiół lotny } \\
\text { Replacement } \\
\text { of } 10 \% \text { of cement } \\
\text { on fly ash }\end{array}$ & $\begin{array}{c}\text { Dodatek } 15 \% \\
\text { popiołu lotnego } \\
\text { do określonej ilości } \\
\text { cementu } \\
\text { Addition of } 15 \% \text { fly } \\
\text { ash to a specified } \\
\text { quantity of cement }\end{array}$ & $\begin{array}{c}\text { Zamiana } 15 \% \\
\text { cementu } \\
\text { na popiół lotny } \\
\text { Replacement } \\
\text { of } 15 \% \text { of cement } \\
\text { on fly ash }\end{array}$ \\
\hline Kruszywo - Aggregate & 155,508 & 155,508 & 155,508 & 155,508 & 155,508 \\
\hline Woda - Water & 11,589 & 11,589 & 11,589 & 11,589 & 11,589 \\
\hline Cement - Cement & 20,860 & 20,860 & 18,774 & 20,860 & 17,731 \\
\hline Popiół - Ash & - & 2,086 & 2,086 & 3,129 & 3,129 \\
\hline
\end{tabular}

- 48,7 MPa (47,7-49,7), z dodatkiem $15 \%$ popiołu - 46,7 MPa $(46,2-47,4)$ oraz z zamianą $15 \%$ cementu na popiół - 40,9 MPa $(39,8-42,2)$.

Badania wymywania zrealizowano tylko dla próbek z dodatkiem 15\% popiołu, zakładając, że wystąpi dla nich największa zawartość metali ciężkich w eluacie. Próbki te po badaniach wytrzymałościowych poddano dodatkowemu mechanicznemu rozdrobnieniu. Uzyskany materiał przesiano przez sita, aby uzyskać frakcję o uziarnieniu poniżej $1 \mathrm{~mm}$ oraz poniżej $4 \mathrm{~mm}$ (rys. 1c i d).

Uzyskane granulaty wysuszono do stałej masy, a następnie dla frakcji poniżej $4 \mathrm{~mm}$ przeprowadzono badania wymywania według normy PN-EN 12457-2:2006. Charakteryzowanie odpadów. Wymywanie. Badanie zgodności w odniesieniu do wymywania ziarnistych materiałów odpadowych i osadów. Część 2: Jednostopniowe badanie porcjowe przy stosunku cieczy do fazy stałej $101 / \mathrm{kg}$ w przypadku materiałów wielkości cząstek poniżej $4 \mathrm{~mm}$ (bez redukcji lub z redukcją wielkości). Zgodnie z normą do uzyskanej frakcji dodano wodę o stopniu czystości 3 (PN-EN ISO 3696:1999. Woda stosowana w laboratoriach analitycznych. Wymagania i metody badań), tak aby stosunek wody do suchej masy $(L / S)$ wynosił $10 \mathrm{dm}^{3} \cdot \mathrm{kg} \mathrm{s.m} .^{-1}$, a następnie wytrząsano przez okres $24 \mathrm{~h}$. Uzyskaną ciecz przesączono przez sączek membranowy o średnicy porów $0,45 \mu \mathrm{m}$. Według procedury zawartej w powyższej normie dodatkowo wykonano badania dla frakcji poniżej $1 \mathrm{~mm}$, aby określić, czy większe rozdrobnienie próbki wpłynie na wyższe stężenia metali ciężkich w eluacie.

Celem zmierzenia stężeń metali ciężkich w eluacie dla każdej frakcji przygotowano cztery próbki. Dwie z nich nie były mineralizowane, a pozostałe dwie poddano mineralizacji mikrofalowej. Mineralizacja polega na rozkładzie i utlenieniu związków organicznych zawartych w próbce, przeprowadzeniu składników do roztworu i utrzymaniu w nim pierwiastków bez strat. Uważa się, że mineralizacja pozwala na uzyskanie bardziej miarodajnych wyników. W tym celu $5 \mathrm{ml}$ próbki rozkładano w obecności $7 \mathrm{ml}$ ultraczystego 65 -procentowego kwasu azotowego V i $1 \mathrm{ml}$ perhydrolu $\left(30 \% \mathrm{H}_{2} \mathrm{O}_{2}\right)$ w piecu mikrofalowym firmy MILESTONE 1200 MEGA, przy maksymalnej mocy mikrofal $650 \mathrm{~W}$, w czasie 18 minut. Po mineralizacji powstały roztwór przeniesiono za pomocą wody dejonizowanej do objętości $30 \mathrm{ml}$. W wyniku mineralizacji próbka została rozcieńczona 6 razy.

Dla próbek mineralizowanych oraz bez mineralizacji wykonano oznaczenia stężeń wybranych metali ciężkich metodą atomowej spektrofotometrii emisyjnej z plazmą wzbudzoną indukcyjnie na spektrometrze ICP-AES Thermo Scientific iCAP 6500. Jako gaz nośny zastosowano argon o czystości 99,9\%. Oznaczenia wykonano 
a

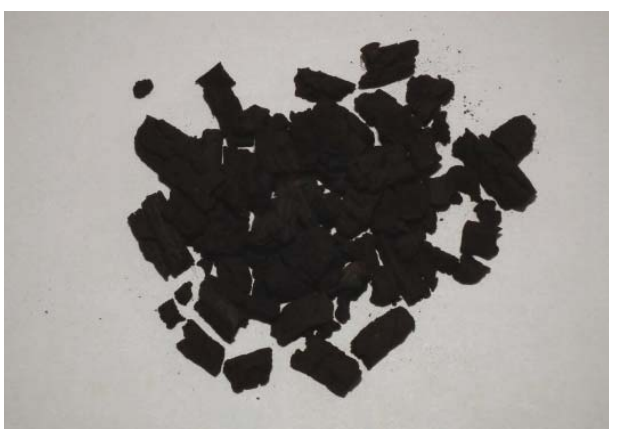

c

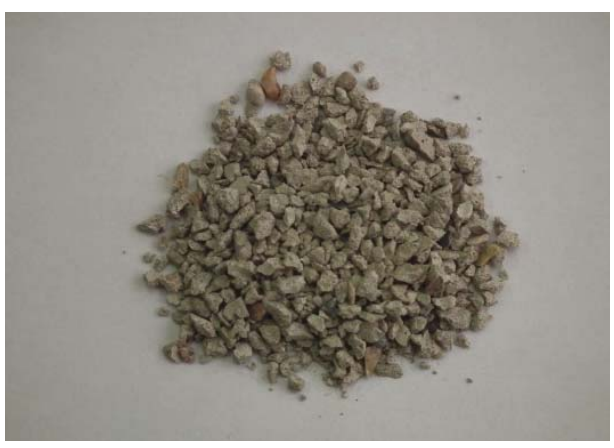

b

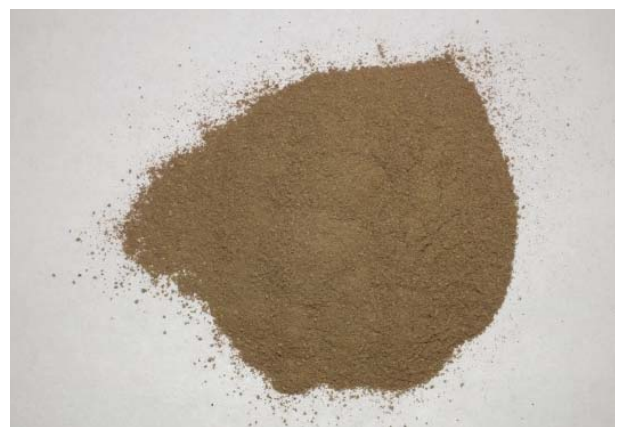

d

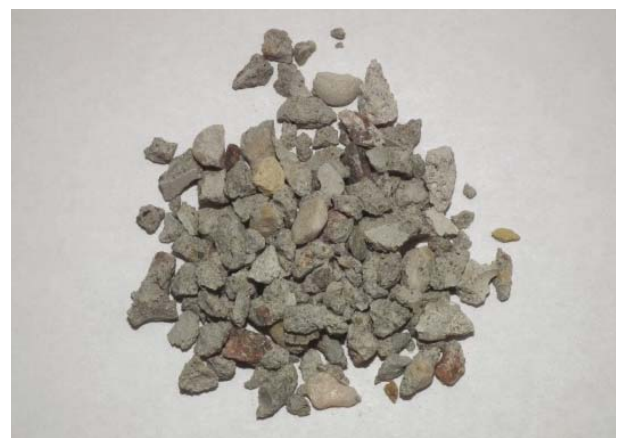

Rys. 1. Materiał wykorzystany do badań: a - wysuszony termicznie osad ściekowy, b - popiół lotny ze spalania osadów ściekowych, c - beton po rozdrobnieniu do granulacji poniżej $1 \mathrm{~mm}, \mathrm{~d}$ - beton po rozdrobnieniu do granulacji poniżej $4 \mathrm{~mm}$

Fig. 1. Material used in the tests: $\mathrm{a}$ - thermally dried sludge, $\mathrm{b}$ - fly ash produced in sludge incineration, $\mathrm{c}$ - concrete after graining under $1 \mathrm{~mm}, \mathrm{~d}$ - concrete after graining under $4 \mathrm{~mm}$

tylko dla tych metali ciężkich, których największą zawartość obserwowano w popiołach lotnych wykorzystanych do badań (tab. 1), tj. dla kadmu, chromu, miedzi, niklu, ołowiu, cynku, arsenu, antymonu oraz selenu. Badania wymywalności były wykonane w Centrum Analitycznym SGGW.

\section{WYNIKI I DYSKUSJA}

Stężenia metali ciężkich w eluacie dla próbek mineralizowanych oraz próbek bez mineralizacji zestawiono w tabeli 4. Uzyskane wyniki badań wskazują na niskie stężenia metali ciężkich, znacznie poniżej granicznych wartości określanych przy wprowadzaniu ścieków przemysłowych do wód lub do ziemi dla substancji szczególnie szkodliwych dla środowiska wodnego (Rozporządzenie Ministra Środowiska z dnia 18 listopada 2014 r. w sprawie warunków, jakie należy spełnić przy wprowadzaniu ścieków do wód lub do ziemi, oraz w sprawie substancji szczególnie szkodliwych dla środowiska wodnego (Dz.U. z 2014 poz. 1800)), powodujących zanieczyszczenie wód, które powinno być eliminowane (wykaz I) oraz które powinno być ograniczane (wykaz II). Nie stwierdzono znaczącego wpływu badanych granulacji próbek na stężenia metali ciężkich w eluacie, natomiast w przypadku chromu, miedzi i ołowiu zaobserwowano wyższe stężenia tych metali w próbce bez mineralizacji. Wynika to z faktu, że podczas mineralizacji próbka była 6-krotnie rozcieńczona i w konsekwencji stężenia tych metali w próbce były poniżej dolnej granicy oznaczalności. 
Tabela 4. Porównanie stężeń wybranych metali ciężkich w eluacie z najwyższymi dopuszczalnymi wskaźnikami zanieczyszczeń dla oczyszczanych ścieków przemysłowych odprowadzanych do środowiska $\left[\mathrm{mg} \cdot \mathrm{dm}^{-3}\right]$

Table 4. Comparison of contents of selected heavy metals in the eluat and the highest permissible pollution indices for the treated industrial wastes introduced to the environment $\left[\mathrm{mg} \cdot \mathrm{dm}^{-3}\right]$

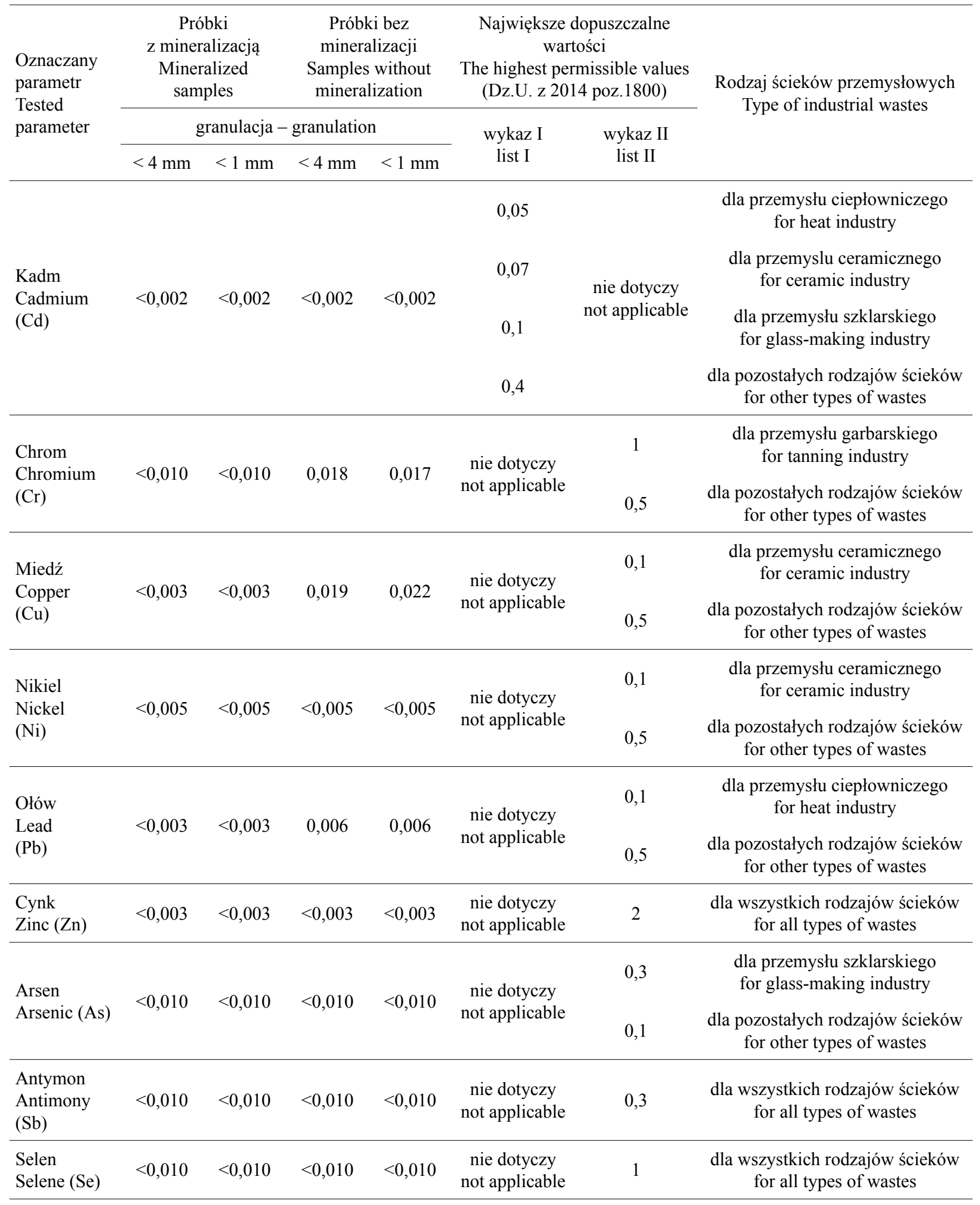


Wichowski, P., Rutkowska, G. i Nowak, P. (2017). Wymywanie wybranych metali ciężkich z betonów zawierających popiół z termicznego przekształcania osadów ściekowych. Acta Sci. Pol. Architectura, 16 (1), 43-51. doi: 10.22630/ASPA.2017.16.1.05.

Uzyskane wyniki porównano również z dopuszczalnymi wartościami wymywania stanowiącymi kryterium dopuszczania odpadów do składowania na składowiskach odpadów danego typu (tab. 5) - Rozporządzenie Ministra Gospodarki z dnia 16 lipca 2015 r. w sprawie dopuszczania odpadów do składowania na składowiskach (Dz.U. z 2015 poz. 1277).

Tabela 5. Porównanie wartości wymywania metali ciężkich z betonu z wartościami dopuszczającymi do składowania odpadów danego typu $\left[\mathrm{mg} \cdot \mathrm{kg} \mathrm{s} . \mathrm{m}^{-1}\right]$

Table 5. Comparison of the values of elution of heavy metals from concrete with the values passing them as fit for storage on dumps of the given type $\left[\mathrm{mg} \cdot \mathrm{kg} \mathrm{d} . \mathrm{m}^{-1}{ }^{-1}\right.$

\begin{tabular}{|c|c|c|c|c|c|c|c|}
\hline \multirow{3}{*}{$\begin{array}{l}\text { Oznaczany parametr } \\
\text { Tested parameter }\end{array}$} & \multicolumn{2}{|c|}{$\begin{array}{c}\text { Próbki } \\
\text { z mineralizacją } \\
\text { Mineralized samples }\end{array}$} & \multicolumn{2}{|c|}{$\begin{array}{l}\text { Próbki bez } \\
\text { mineralizacji } \\
\text { Samples without } \\
\text { mineralization }\end{array}$} & \multicolumn{3}{|c|}{$\begin{array}{l}\text { Graniczne wartości wymywania przy dopuszczaniu } \\
\text { do składowaniu odpadów } \\
\text { Limit values of elution passing waste as fit for } \\
\text { storage (Dz. U. z } 2015 \text { poz. 1277) }\end{array}$} \\
\hline & \multicolumn{4}{|c|}{ granulacja - granulation } & \multirow[b]{2}{*}{$\begin{array}{c}\text { obojętnych } \\
\text { neutral waste }\end{array}$} & \multirow{2}{*}{$\begin{array}{l}\text { innych niż obojętne } \\
\text { i niebezpieczne } \\
\text { other waste } \\
\text { than neutral } \\
\text { and dangerous }\end{array}$} & \multirow{2}{*}{$\begin{array}{l}\text { niebezpiecz- } \\
\text { nych } \\
\text { dangerous } \\
\text { waste }\end{array}$} \\
\hline & $<4 \mathrm{~mm}$ & $<1 \mathrm{~mm}$ & $<4 \mathrm{~mm}$ & $<1 \mathrm{~mm}$ & & & \\
\hline Kadm - Cadmium $(\mathrm{Cd})$ & $<0,002$ & $<0,002$ & $<0,002$ & $<0,002$ & $0,04^{\mathrm{a}}(0,03)^{\mathrm{b}}$ & $1(0,6)$ & $5(3)$ \\
\hline Chrom - Chromium $(\mathrm{Cr})$ & $<0,010$ & $<0,010$ & 0,018 & 0,017 & $0,5(0,2)$ & $10(4)$ & $70(25)$ \\
\hline Miedź - Copper $(\mathrm{Cu})$ & $<0,003$ & $<0,003$ & 0,019 & 0,022 & $2(0,9)$ & $50(25)$ & $100(50)$ \\
\hline Nikiel - Nickel (Ni) & $<0,005$ & $<0,005$ & $<0,005$ & $<0,005$ & $0,4(0,2)$ & $10(5)$ & $40(20)$ \\
\hline Ołów - Lead (Pb) & $<0,003$ & $<0,003$ & 0,006 & 0,006 & $0,5(0,2)$ & $10(5)$ & $50(25)$ \\
\hline Cynk - Zinc (Zn) & $<0,003$ & $<0,003$ & $<0,003$ & $<0,003$ & $4(2)$ & $50(25)$ & $200(90)$ \\
\hline Arsen - Arsenic (As) & $<0,010$ & $<0,010$ & $<0,010$ & $<0,010$ & $0,5(0,1)$ & $2(0,4)$ & $25(6)$ \\
\hline Antymon - Antimony (Sb) & $<0,010$ & $<0,010$ & $<0,010$ & $<0,010$ & $0,06(0,02)$ & $0,7(0,2)$ & $5(2)$ \\
\hline Selen - Selene (Se) & $<0,010$ & $<0,010$ & $<0,010$ & $<0,010$ & $0,1(0,06)$ & $0,5(0,3)$ & $7(4)$ \\
\hline
\end{tabular}

${ }^{\text {a }}$ Test podstawowy: ciecz/faza stała $=10 \mathrm{dm}^{3} \cdot \mathrm{kg} \mathrm{s} \cdot \mathrm{m}^{-1}$ - Base test: liquid $/$ solid phase $(L / S)=10 \mathrm{dm}^{3} \cdot \mathrm{kg} \mathrm{of} \mathrm{solid}^{-1}$.

${ }^{\mathrm{b}}$ Test pomocniczy: ciecz/faza stała $=2 \mathrm{dm}^{3} \cdot \mathrm{kg} \mathrm{s} \cdot \mathrm{m}^{-1}-$ Auxiliary test: liquid/solid phase $(L / S)=2 \mathrm{dm}^{3} \cdot \mathrm{kg}$ of solid ${ }^{-1}$.

Pomierzone wartości wymywania metali ciężkich z badanych próbek betonu w większości przypadków są poniżej granicy oznaczalności, pomimo zastosowania metody atomowej spektrofotometrii emisyjnej i wzorców pozwalających na określenie stężeń na poziomie ppb (liczba części na miliard). Na podstawie uzyskanych wyników można wnioskować, że oddziaływanie takich betonów na środowisko naturalne związane z uwalnianiem metali ciężkich jest nieznaczne. Należy jednak zaznaczyć, że zrealizowane badania są badaniami wstępnymi. Planuje się je poszerzyć m.in. o oznaczenie wymywania metali j.w. przy zróżnicowaniu odczynu pH wymywającej cieczy, ilości i rodzaju cementu, stosunku w/c mieszanki betonowej, klasy ekspozycji betonu, sposobu wymywania.

\section{PODSUMOWANIE I WNIOSKI}

Wykorzystanie odpadów do produkcji materiałów budowlanych staje się coraz bardziej powszechne. Praktyka ta może jednak powodować zwiększone oddziaływanie takich materiałów na środowisko naturalne. Zasady 
Wichowski, P., Rutkowska, G. i Nowak, P. (2017). Wymywanie wybranych metali ciężkich z betonów zawierających popiół z termicznego przekształcania osadów ściekowych. Acta Sci. Pol. Architectura, 16 (1), 43-51. doi: 10.22630/ASPA.2017.16.1.05.

uwzględniania oddziaływania na środowisko materiałów, z jakich są wykonane konstrukcje z betonu, są najmłodszą dziedziną i nie doczekały się jeszcze międzynarodowych norm (Ajdukiewicz, 2011). Brak jest kompleksowych wytycznych i przepisów prawnych dotyczących oddziaływania materiałów budowlanych na środowisko, w tym na środowisko wodne. Uważa się, iż potencjalnym zagrożeniem przy wykorzystaniu popiołów ze spalania osadów ściekowych do produkcji betonu jest migracja metali ciężkich do środowiska wodnego. Dotychczasowe badania wskazują jednak na wysoki stopień unieruchomienia metali ciężkich zarówno w samych popiołach, jak i popiołach zestalonych (Giergiczny i Król, 2008; Białowiec, Janczukowicz i Krzemieniewski, 2009; Borowski, 2011; Kępys, Pomykała i Pietrzyk, 2013; Smol, Kulczycka, Henclik, Gorazda i Wzorek, 2015). Uzyskane wyniki badań potwierdzają, że migracja metali ciężkich do środowiska wodnego jest nieznaczna i nie powinna stanowić istotnego problemu. Celowe jest jednak prowadzenie dalszych badań dla zmiennych klas i rodzajów betonu oraz zróżnicowanych warunków wymywania.

\section{PIŚMIENNICTWO}

Ajdukiewicz, A. (2011). Beton a środowisko-zasady projektowania konstrukcji betonowych z uwagi na trwałość $i$ wplyw na środowisko. Materiały z XXV Konferencji Naukowo-Technicznej „Awarie budowlane”, Międzyzdroje, Polska.

Białowiec, A., Janczukowicz, W. i Krzemieniewski, M. (2009). Możliwości zagospodarowania popiołów po termicznym unieszkodliwianiu osadów ściekowych w aspekcie regulacji prawnych. Rocznik Ochrona Środowiska-Annual Set The Environment Protection, 11, 959-971.

Bień, J. D. (2012). Zagospodarowanie komunalnych osadów ściekowych metodami termicznymi. Inżynieria i Ochrona Środowiska, 15(4), 439-449.

Borowski, G. (2011). Przetwarzanie popiołu ze spalania osadów ściekowych na materiał budowlany. Inżynieria Ekologicz$n a, 25,251-258$.

Gawdzik, J. i Latosińska, J. (2014). Ocena immobilizacji metali ciężkich z popiołów ze spalania osadów ściekowych. Inżynieria i Ochrona Środowiska, 17(3), 415-421.

Giergiczny, Z. i Król, A. (2008). Immobilization of heavy metals ( $\mathrm{Pb}, \mathrm{Cu}, \mathrm{Cr}, \mathrm{Zn}, \mathrm{Cd}, \mathrm{Mn})$ in the mineral additions containing concrete composites. Journal of Hazardous Materials, 160, 247-255. doi: 10.1016/j.jhazmat.2008.03.007.

Główny Urząd Statystyczny [GUS] (2017). Ochrona środowiska 2015, Warszawa. Pobrano z lokalizacji: http://www.stat. gov.pl.

Jamroży, Z. (2009). Beton i jego technologie. Warszawa: Wydawnictwo Naukowe PWN.

Kępys, W., Pomykała, R. i Pietrzyk, J. (2013). Właściwości popiołów lotnych z termicznego przekształcania komunalnych osadów ściekowych. Inżynieria Mineralna - Journal of the Polish Mineral Engineering Society, styczeń - czerwiec, $11-18$.

Kosior-Kazberuk, M. (2011). Nowe dodatki mineralne do betonu. Budownictwo i Inżynieria Środowiska, 2, 47-55.

Pietrzak, A. (2014). Proekologiczne technologie w budownictwie na przykładzie „zielonego betonu”. Budownictwo o zoptymalizowanym potencjale energetycznym, 1 (13), 86-93.

PN-EN 206:2014-04. Beton. Wymagania, właściwości, produkcja i zgodność.

PN-EN 450-1:2009. Popiół lotny do betonu. Część 1: Definicje, specyfikacje i kryteria zgodności.

PN-EN 12457-2:2006. Charakteryzowanie odpadów. Wymywanie. Badanie zgodności w odniesieniu do wymywania ziarnistych materiałów odpadowych i osadów. Część 2: Jednostopniowe badanie porcjowe przy stosunku cieczy do fazy stałej 10 l/kg w przypadku materiałów o wielkości cząstek poniżej 4 mm (bez redukcji lub z redukcją wielkości).

PN-EN ISO 3696:1999. Woda stosowana w laboratoriach analitycznych. Wymagania i metody badań.

Rozporządzenie Ministra Gospodarki z dnia 16 lipca 2015 r. w sprawie dopuszczania odpadów do składowania na składowiskach (Dz.U. z 2015 poz. 1277).

Rozporządzenie Ministra Środowiska z dnia 18 listopada 2014 r. w sprawie warunków, jakie należy spełnić przy wprowadzaniu ścieków do wód lub do ziemi, oraz w sprawie substancji szczególnie szkodliwych dla środowiska wodnego (Dz.U. z 2014 poz. 1800).

Rutkowska, G. i Iwaszko, M. (2015). Wpływ popiołów lotnych ze spalania osadów ściekowych na wytrzymałość i mrozoodporność betonów drobnoziarnistych. Inżynieria Ekologiczna, 45, 59-67. 
Wichowski, P., Rutkowska, G. i Nowak, P. (2017). Wymywanie wybranych metali ciężkich z betonów zawierających popiół z termicznego przekształcania osadów ściekowych. Acta Sci. Pol. Architectura, 16 (1), 43-51. doi: 10.22630/ASPA.2017.16.1.05.

Rutkowska, G., Wichowski, P. i Mroczkowska, A. (2016). Kształtowanie właściwości betonu zwykłego na bazie cementów z dodatkiem włókien stalowych i popiołu lotnego. Acta Sci. Pol. Architectura, 15(3), 71-80.

Rutkowska, G., Wiśniewski, K., Chalecki, M., Górecka, M. i Miłosek, K. (2016). Influence of fly-ashes on properties of ordinary concretes. Annals of Warsaw University of Life Sciences - SGGW, Land Reclamation, 48(1), $79-94$.

Smol, M., Kulczycka, J., Henclik, A., Gorazda, K. i Wzorek, Z. (2015). Możliwości zastosowania odpadów po termicznym przekształceniu osadów ściekowych w materiałach budowlanych. W A. Kotowski, K. Piekarska i B. Kaźmierczak, Interdyscyplinarne zagadnienia $w$ inżynierii i ochronie środowiska. Wrocław: Oficyna Wydawnicza Politechniki Wrocławskiej.

Uchwała nr 88 Rady Ministrów z dnia 1 lipca 2016 r. w sprawie Krajowego planu gospodarki odpadami 2022 (2017). Pobrano z lokalizacji: http://www.monitorpolski.gov.pl/mp/2016/784/1.

Wang, C., Hu, X., Chen, M. L. i Wu, Y. H. (2005). Total concentrations as fractions of Cd, Cr, Pb, Cu, Ni and Zn in sewage sludge from municipal and industrial wastewater treatment plants. Journal of Hazardous Materials, B119, 245-249. doi: 10.1016/j.jhazmat.2004.11.023.

Wilk, M. i Gworek, B. (2009). Metale ciężkie w osadach ściekowych. Ochrona Środowiska i Zasobów Naturalnych, 39, 40-59.

\title{
ELUTION OF SELECTED HEAVY METALS FROM CONCRETES CONTAINING ASHES PRODUCED IN THERMAL CONVERSION OF SLUDGE
}

\begin{abstract}
The aim of the paper was to determine values concerning elution of selected heavy metals from the C16/20 ordinary concretes containing fly ashes which had been produced in thermal conversion of sludge and constitute $15 \%$ of the calculated cement amount. The concrete samples were comminuted into two fractions - with graining under $4 \mathrm{~mm}$ and under $1 \mathrm{~mm}$ - which were subjected to elution and then the content of $\mathrm{Cd}, \mathrm{Cr}, \mathrm{Cu}$, $\mathrm{Ni}, \mathrm{Pb}, \mathrm{Zn}, \mathrm{As}, \mathrm{Sb}$ and $\mathrm{Se}$ in the resulting eluat was assayed. The heavy metal contents which have been determined are considerably lower than the maximum values defined in the directives which must be fulfilled during introduction of sewages to water or soil - i.a. the directives on the substances which are particularly harmful for the water environment and on elution limit values required for wastes to pass them as fit for storage on dumps. It has been stated on these grounds that the migration of heavy metals from concretes with admixture of fly-ashes is negligible and probably does not present problems. However, the investigations require to be continued for various classes and types of concrete and for diversified conditions of elution.
\end{abstract}

Key words: ash produced in thermal conversion of sludge, heavy metals, leaching 